\title{
PENGARUH RETURN ON ASSET DAN RETURN ON EQUITY TERHADAP PERTUMBUHAN LABA PADA PERUSAHAAN SUB SEKTOR WHOLESALE YANG TERDAFTAR DI BURSA EFEK INDONESIA
}

\author{
${ }^{1}$ Rima Sundari, ${ }^{2}$ M. Rizal Satria \\ Program Studi Diploma IV Akuntansi Keuangan \\ Politeknik Pos Indonesia \\ rimasundari@poltekpos.ac.id, rizalstr@gmail.com
}

\begin{abstract}
ABSTRAK
Dalam dunia perdagangan saat ini banyak sekali perusahaan yang bergerak di bidang manufacture dan perusahaan ritel menjual produk. Sebagian besar pasar ritel mendapatkan produk mereka melalui perusahaan distribusi. Distribusi dapat diartikan sebagai kegiatan pemasaran yang berusaha memperlancar dan mempermudah penyampaian barang dan jasa dari produsen kepada konsumen. Penelitian ini dilakukan untuk mengetahui bagaimana pengaruh return on asset dan return on equity terhadap pertumbuhan laba perusahaan sub sektor wholesale. Jenis penelitian yang digunakan menggunakan metode penelitian kuantitatif dengan data sekunder. Return on asset dan return on equity sebagai variable independen. Pertumbuhan laba sebagai variable dependen. Sampel yang digunakan adalah laporan keuangan tahunan pada tahun 2017 sampai 2019. Adapun alat analisis yang di gunakan Uji Normalitas, Korelasi Product Moment, Korelasi Berganda, Koefisien Determinasi, Uji t, dan Uji F. Hasil penelitian ini menunjukan bahwa secara simultan dinyatakan bahwa, return on asset dan return on equity tidak berpengaruh signifikan terhadap pertumbuhan laba.
\end{abstract}

Kata Kunci: Return on Asset, Return on Equity, Pertumbuhan Laba

\section{ABSTRACT}

In today's trading world, there are many companies engaged in manufacture and retail companies selling products. Most of the retail market gets their products through distribution companies. Distribution can be defined as a marketing activity that seeks to facilitate and facilitate the delivery of goods and services from producers to consumers. This research was conducted to determine how the effect of return on assets and return on equity on profit growth wholesale sub-sector companies. This type of research uses quantitative research methods with secondary data. Return on assets and return on equity as independent variables. Profit growth as the dependent variable. The sample used is the annual financial statements from 2017 to 2019. The analysis tools used are the Normality Test, Product Moment Correlation, Multiple Correlation, Determination Coefficient, $t$ test, and $F$ test. The results of this study show that simultaneously it is stated that, return on assets and return on equity have no significant effect on profit growth.

Keywords: Return on Assets, Return on Equity, Profit Growth

\section{PENDAHULUAN}

Dalam bisnis perdagangan saat ini banyak sekali perusahaan yang bergerak di bidang manufacture dan perusahaan retail. Sebagian besar pasar retail mendapatkan produk 
melalui perusahaan distribusi. Distribusi diartikan sebagai suatu kegiatan pemasaran yang berguna untuk mempermudah pendistribusian barang dari produsen kepada konsumen, sehingga kegunaannya sesuai dengan yang diperlukan (jenis, jumlah, harga, tempat, dan saat dibutuhkan). Perusahaan distributor merupakan perantara untuk menyalurkan produk dari produsen ke retail.

Pada dasarnya untuk melihat kemajuan perushaan dapat di lihat dari laba yan di hasilkan oleh perushaan. Laba perusahaan dapat menentukan kelangsungan kehidupan jangka panjang perusahaan tersebut dan ketika laba perusahaan meningkat maka akan meningkatkan keuntungan bagi pemilik saham. Di sisi lain, laba perusahaan yang tinggi akan meningkatkan pertumbuhan usaha karena meningkatnya atau besar salah satu sumber modal juga tergantung pada besar laba yang dicapai oleh perusahaan sangat penting untuk perusahaan melakukan pengambilan keputusan untuk mendapatkan laba. Sebuah keputusan bagi perusahaan dapat dilihat dari laporan keuangan.

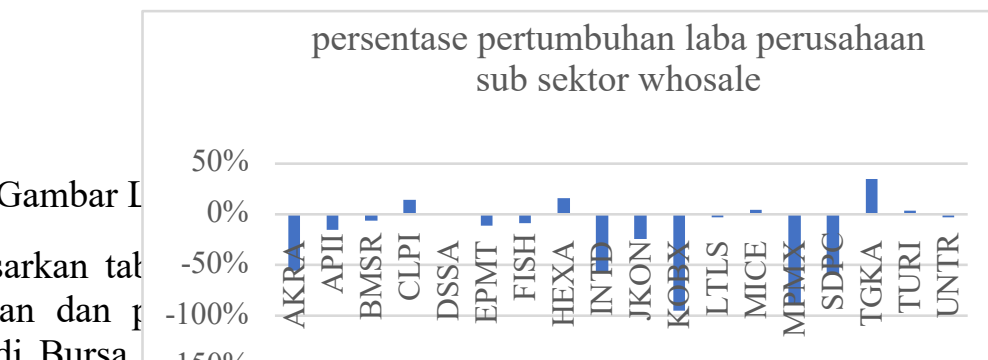

BEI

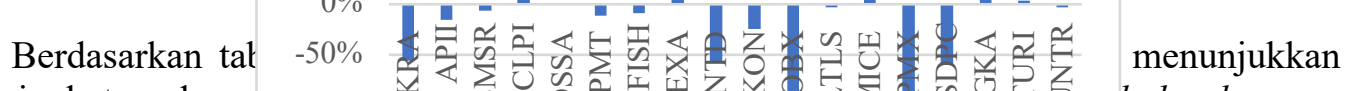

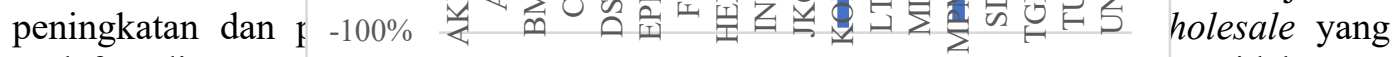
terdaftar di Bursa $-150 \%$ an tidak tetap

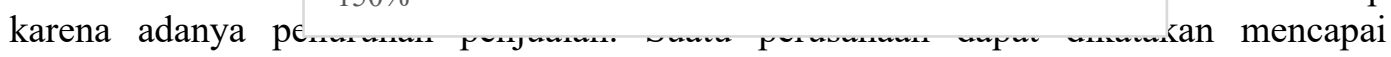
kesuksesan dan memenangkan persaingan apabila dapat menghasilkan laba yang maksimal.

Suatu perusahaan dapat dikatakan mencapai kesuksesan dan berhasil memenangkan persaingan apabila dapat menghasilkan laba yang maksimal. Laba mencerminkan pengembalian kepada pemegang ekuitas untuk periode yang bersangkutan.

Untuk memperoleh informasi keuangan yang relevan dengan tujuan dan kepentingan pemakai, maka informasi keuangan yang disajikan harus terlebih dahulu dianalisis sehingga dihasilkan keputusan bisnis yang tepat. Laporan keuangan menjadi lebih berarti apabila dapat dipahami dan dimengerti oleh berbagai pihak, oleh karena itu perlu dilakukan analisis terhadap laporan keuangan.

Laporan keuangan merupakan catatan informasi keuangan suatu perusahaan pada suatu periode tertentu yang digunakan untuk mengambarkan kinerja suatu perusahaan. Kinerja perusahaan merupakan hal yang sangat penting dapat digunakan sebagai alat untuk mengetahui apakah perusahaan mengalami perkembangan atau sebaliknya.

Analisis laporan keuangan perlu dilakukan secara cermat dengan menggunakan metode dan teknik analisis yang tepat sehingga hasil yang diharapkan sesuai dengan pencapaian yang akan diperoleh. Teknik analisis yang biasa digunakan adalah analisis rasio keuangan.

Rasio keuangan merupakan alat analisis keuangan perusahaan untuk menilai kinerja suatu perusahaan berdasarkan perbandingan yang terdapat pada laporan keuangan. Analisis rasio dapat digunakan untuk membimbing investor dan kreditor dalam membuat suatu keputusan atau pertimbangan tentang pencapaian perusahaan pada masa yang akan datang. 
Rasio keuangan sebagai salah satu informasi yang dapat digunakan untuk memprediksi kinerja keuangan perusahaan atau laba di masa mendatang. Perubahan indikator kinerja keuangan itu akan mempengaruhi kebijakan keuangan untuk kegiatan selanjutnya, seperti kebijakan mengenai dividen, pembayaran utang, penyisihan, investasi, dan menjaga kelangsungan kegiatan perusahaan.

Adapun rasio keuangan yang dapat digunakan untuk mengukur keefektifan dan keefisienan dari aktivitas perusahaan sehingga dapat memprediksi pertumbuhan laba di masa yang akan datang, rasio yang digunakan adalah Return On Asset dan Return On Equity.

Menurut (Sartono, 2015:123) Return on Assets menunjukan kemampuan perusahaan menghasilkan laba dari aktiva yang dipergunakan. Return on Equity adalah rasio untuk mengukur laba bersih sesudah pajak Menurut (Kasmir, 2015:204) Return on Equity merupakan Rasio yang menunjukkan daya untuk menghasilkan laba atas investasi berdasarkan nilai buku para pemegang saham. Semakin tinggi rasio ini, semakin baik, artinya posisi pemilik perusahaan semakin kuat.

\section{Identifikasi Masalah}

Berdasarkan latar belakang yang telah dipaparkan diatas, identifikasi masalah dalam penelitian ini, yaitu:

1. Bagaimana pengaruh Return on Asset terhadap Pertumbuhan Laba pada perusahaan sub sektor wholesale yang terdaftar di Bursa Efek Indonesia tahun 2017-2019?

2. Bagaimana pengaruh Return on Equity terhadap Pertumbuhan Laba pada perusahaan sub sektor wholesale yang terdaftar di Bursa Efek Indonesia tahun 2017-2019?

3. Bagaimana pengaruh Return on Asset dan Return on Equity terhadap pertumbuhan laba pada perusahaan sub sektor wholesale yang terdaftar di Bursa Efek Indonesia tahun 2017-2019?

\section{KAJIAN PUSTAKA}

Merupakan ringkasan atau rangkuman dan teori yang ditemukan dari sumber bacaan yang ada kaitannya tema yang akan diangkat dalam penelitian

\section{Laporan keuangan}

Laporan keuangan merupakan hasil dari proses akuntansi yang digunakan sebagai alat komunikasi antara data keuangan suatu perusahaan dengan pihak-pihak yang berkepentingan dengan data atau aktivitas perusahaan tersebut.

Berdasarkan (PSAK, 2015) tujuan laporan keuangan adalah menyediakan informasi yang menyangkut posisi keuangan, kinerja serta perubahan posisi keuangan suatu perusahaan yang bermanfaat bagi sejumlah besar pemakai dalam pengambilan keputusan ekonomi. Keputusan ini mungkin mencakup misalnya, keputusan untuk menahan atau menjual investasi mereka dalam perusahaan atau keputusan untuk mengangkat kembali atau mengganti manajemen.

\section{Rasio Keuangan}

Menurut (Kasmir, 2015:104) Rasio keuangan adalah kegiatan membandingkan angka-angka yang ada dalam laporan keuangan. Menurut (Harahap, 2015:297) rasio keuangan adalah angka yang diperoleh dari hasil perbandingan dari satu pos laporan keuangan dengan pos lainnya yang mempunyai hubungan yang relevan dan signifikan.

Tujuan analisis rasio keuangan menurut (Munawir, 2015:64) adalah sebagai berikut: 
1. Untuk keperluan pengukuran kerja keuangan secara menyeluruh (overall measures)

2. Untuk keperluan pengukuran profitabilitas atau rentabilitas, kemampuan perusahaan untuk memperoleh keuntungan dari operasinya (profitability measures)

3. Untuk keperluan pengujian investasi (test of invetsment utylization)

4. Untuk keperluan pengujian kondisi keuangan antara lain tentang tingkat likuiditas dan solvabilitas (test of finance condition)

\section{Rasio Profitabilitas}

Setiap perusahaan bertujuan untuk memperoleh keuntungan atau laba. "Manajemen perusahaan dituntut untuk mencapai target tertentu yang sudah direncanakan sebelumnya. Salah satu alat analisis untuk menganalisis kemampuan perusahaan dalam menghasilkan laba yang biasanya dilakukan adalah rasio profitabilitas. Semakain baik rasio profitabilitas maka menggambarkan tingginya perolehan keuntungan perusahaan.

\section{Return on Asset}

Menurut (Kasmir, 2015:201) menyatakan bahwa return on assets merupakan rasio yang menunjukan hasil (return) atas jumlah aktiva yang digunakan dalam perusahaan. Rasio ini berguna bagi pihak manajemen untuk mengevaluasi efektivitas dan efisiensi manajemen perusahaan dalam mengelola aktiva perusahaan. Semakin besar ROA, berarti semakin efisien penggunaan aktiva perusahaan.

Rumus yang digunakan dalam menentukan ROA adalah

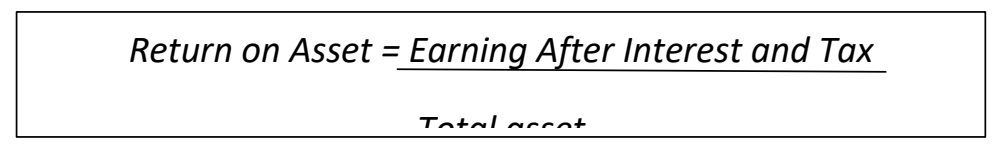

\section{Return on Equity}

Menurut (Kasmir, 2015:204) return on equity adalah rasio untuk mengukur laba bersih sesudah pajak dengan modal sendiri. Rasio ini menunjukkan daya untuk menghasilkan laba atas investasi berdasarkan nilai buku para pemegang saham. Semakin tinggi rasio ini, semakin baik, artinya posisi pemilik perusahaan semakin kuat.

Rumus yang digunakan untuk menentuka ROE adalah

Return on Equity $=$ Earning After Interest and Tax

\section{Pertumbuhan Laba}

Menurut (Harahap, 2015:310) pertumbuhan laba adalah rasio yang menunjukkan kemampuan perusahaan meningkatkan laba bersih dibanding tahun sebelumnya. Menurut (Hapsari, 2017) Pertumbuhan laba adalah perubahan persentasi kenaikan laba yang diperoleh perusahaan. Pertumbuhan laba perusahaan yang baik akan menunjukkan bahwa perusahaan mempunyai keuangan yang baik, yang pada akhirnya akan meningkatkan nilai perusahaan. Pertumbuhan laba adalah persentase kenaikan laba yang diperoleh perusahaan.

Pertumbuhan Laba menurut (Harahap, 2015:310) dapat hitung dengan rumus sebagai berikut:

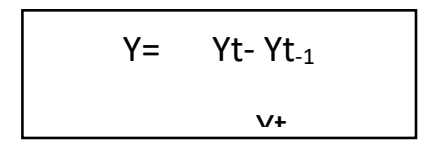


Keterangan:

$\mathrm{Y}=$ Pertumbuhan Laba

$\mathrm{Yt}=$ Laba setelah pajak periode berjalan

Yt-1 = Laba setelah pajak periode sebelumnya

Dengan demikian dapat di simpulkan bahwa laba merupakan kemampuan perusahaan dalam memperoleh keuntungan dalam suatu periode.

\section{METODE PENELITIAN}

Penelitian ini menggunakan pendekatan kuantitatif dengan menerapkan metode pendekatan asosiatif karena penelitian yang bertujuan untuk mengetahui pengaruh ataupun juga hubungan antara dua variabel atau lebih.

Teknik pengambilan sampel yang digunakan dalam penelitian ini adalah teknik purposive sampling. Adapun kriteria dalam pengambilan sampel dalam penelitian ini yaitu:

1. Perusahaan sub sektor wholesale yang terdaftar di BEI dalam periode 2017 - 2019

2. Perusahaan tersebut telah menerbitkan laporan keuangannya tahun periode yang berakhir 31 desember dalam kurun waktu penelitian periode 2017 -2019

3. Perusahaan yang menyediakan data yang akan digunakan sebagai variable penelitian atau memiliki data yang lengkap untuk keperluan penelitian.

4. Perusahaan yang mencetak kinerja positif selama periode 2017- 2019 di lihat dari perusahaan yang mencetak laba selama tahun penelitian.

Penelitian ini di lakukan pada tahun 2017-2019 dengan sample sebanyak 15 perusahaan sub sektor wholesale maka di peroleh sample sebanyak $15 \times 3=45$ sampel.

Data yang digunakan dalam penelitian ini menggunankan laporan keuangan perushaan yang di peroleh melalui website resmi bursa efek indonesia.

\section{HASIL DAN PEMBAHASAN}

Pada bagian ini menejelaskan tentang hasil penelitian yang dilakukan oleh peneliti dengan menggunakan data perusahaan sub sector Wholesale yang terdaftar di Bursa Efek Indonesia

\section{Uji normalitas data}

Uji normalitas digunakan untuk mengetahui distribusi data dalam variabel yang akan digunakan berdistribusi normal atau tidak berdistribusi normal. Berikut adalah tabel hasil uji normalitas yang telah diolah sebagai berikut:

Hasil uji normalitas data

\begin{tabular}{|ll|}
\hline One-Sample Kolmogorov-Smirnov Test \\
\hline & Unstandardized Residual \\
\hline $\mathrm{N}$ & 48 \\
\hline
\end{tabular}




\begin{tabular}{|c|c|c|}
\hline \multirow[t]{2}{*}{ Normal Parameters ${ }^{\mathrm{a}, \mathrm{b}}$} & Mean & .0000000 \\
\hline & Std. Deviation & .45676891 \\
\hline \multirow{3}{*}{$\begin{array}{l}\text { Most } \\
\text { Differences }\end{array}$} & Absolute & .121 \\
\hline & Positive & .121 \\
\hline & Negative & -.066 \\
\hline \multicolumn{2}{|l|}{ Test Statistic } & .121 \\
\hline \multicolumn{2}{|l|}{ Asymp. Sig. (2-tailed) } & $.095^{\mathrm{c}}$ \\
\hline \multicolumn{3}{|l|}{ a. Test distribution is Normal. } \\
\hline \multicolumn{3}{|l|}{ b. Calculated from data. } \\
\hline \multicolumn{3}{|c|}{ c. Lilliefors Significance Correction. } \\
\hline
\end{tabular}

Berdasarkan hasil analisis uji normalitas dan mengacu pada kolom Kolmogorov-Smirnov menunjukan bahwa Variabel Y Pertumbuhan Laba, Variabel X1 Return on asset, Variabel X2 Return on equity memiliki nilai Sig. sebesar 0,095. Dimana angka tersebut menunjukan $0,095 \geq 0,05$ maka dari hasil data tersebut dapat disimpulkan berdistribusi normal.

\section{Analisis Regresi Linier Berganda}

Analisis regresi linier berganda adalah hubungan secara linear antara dua variabel atau lebih variabel independen dimana return on asset (X1), return on equity (X2) terhadap pertumbuhan laba (Y). Berikut adalah hasil dari analisis regresi linear berganda yang telah dilakukan peneliti.

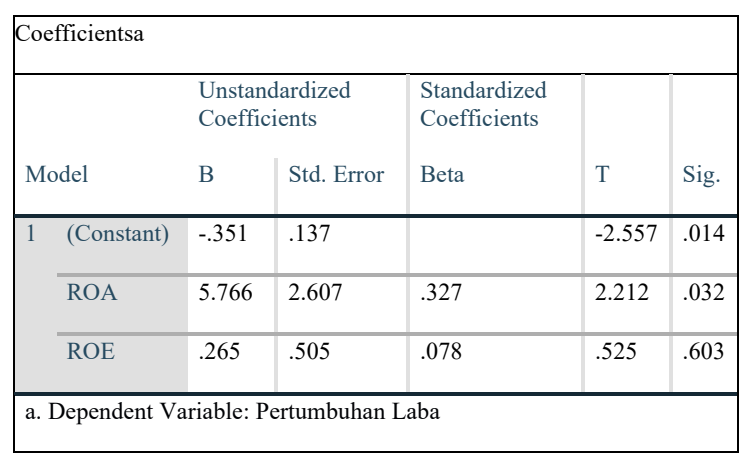

Berdasarkan hasil analisis regresi linier berganda yang dilihat pada tabel, maka didapatkan persamaan sebagai berikut:

\section{Konstanta (a)}

Jika variabel return on asset (X1) dan return on equity (X2) nilainya 0 , maka nilai variabel volume produksi (Y) adalah sebesar -0.351

2. Return on asset (X1) terhadap pertumbuhan laba (Y)

Koefisien regresi variabel return on asset (X1) sebesar 5.766 artinya jika variabel return on asset (X1) mengalami kenaikan 1, maka volume produksi (Y) akan mengalami kenaikan sebesar 5,766. Karena koefisien bernilai positif maka terjadi hubungan positif pula antara return on asset (X1) terhadap pertumbuhan laba (Y). Jadi, kenaikan return on asset (X1) mengakibatkan kenaikan pada pertumbuhan laba (Y).

3. Return on equity (X2) terhadap pertumbuhan laba (Y) 
Koefisien regresi variabel return on equity (X2) sebesar 0.265 artinya jika variabel return on equity (X2) mengalami kenaikan 1, maka pertumbuhan laba (Y) akan mengalami peningkatan sebesar 0,265 . Karena koefisien bernilai positif maka terjadi hubungan positif pula antara biaya return on equity (X2) terhadap pertumbuhan laba (Y).

Jadi, kenaikan return on equity (X2) mengakibatkan peningkatan pada pertumbuhan laba

\section{Analisis Koefisiensi Determinasi}

Koefisien determinasi digunakan untuk mengetahui besarnya pengaruh persentase variabel independen yaitu return on asset (X1) dan return on equity (X2) terhadap variabel dependen yaitu pertumbuhan laba $(\mathrm{Y})$. Berikut adalah tabel hasil analisis koefisien determinasi yang telah diolah sebagai berikut:

\section{Hasil Analisis Koefisien Determinasi}

\begin{tabular}{|c|c|c|c|c|}
\hline \multicolumn{5}{|c|}{ Model Summary $^{\text {b }}$} \\
\hline Model & $\mathrm{R}$ & R Square & $\begin{array}{l}\text { Adjusted } \\
\text { Square }\end{array}$ & $\begin{array}{l}\text { RStd. Error of the } \\
\text { Estimate }\end{array}$ \\
\hline 1 & $352^{\mathrm{a}}$ & .124 & .082 & .467518 \\
\hline \multicolumn{5}{|c|}{ a. Predictors: (Constant), ROE, ROA } \\
\hline
\end{tabular}

Berdasarkan hasil analisis koefisien determinasi menunjukan bahwa nilai dari koefisien determinasi memiliki nilai 0,352 . Berikut perhitungan secara manual untuk mendapatkan R square:

$$
\begin{aligned}
& \mathrm{KD}=\mathrm{r}^{2} \times 100 \% \\
& \mathrm{KD}=(0,352)^{2} \times 100 \%
\end{aligned}
$$

Dari tabel diatas dapat diketahui nilai $\mathrm{R}$ square atau koefisien determinasi adalah 0,124 , maka nilai tersebut mempunyai arti bahwa sebesar $12,4 \%$ variasi dari variabel pertumbuhan laba dapat dipengaruhi oleh return on asset dan return on equity. Sedangkan sisanya yaitu 0,876 atau $87,6 \%$ dari variabel pertumbuhan laba dipengaruhi oleh variabel lainnya (faktor lain) yang tidak dimasukan dalam penelitian ini.

\section{Uji Korelasi Product Moment}

Berikut adalah tabel hasil uji korelasi pearson product moment yang telah diolah sebagai berikut:

Hasil Analisis Korelasi Pearson Product Moment

\begin{tabular}{|lll|l|l|}
\hline Correlations & \multicolumn{5}{l|}{} \\
\hline & & ROA & ROE & Pertumbuhan Laba \\
\hline ROA & Pearson Correlation & 1 & .211 & $.343^{*}$ \\
\cline { 2 - 5 } & Sig. (2-tailed) & & .164 & .021 \\
\hline
\end{tabular}




\begin{tabular}{|lll|l|l|}
\hline & $\mathrm{N}$ & 45 & 45 & 45 \\
\hline ROE & Pearson Correlation & .211 & 1 & .147 \\
\cline { 2 - 6 } & Sig. (2-tailed) & .164 & 45 & .337 \\
\cline { 2 - 5 } & $\mathrm{N}$ & 45 & .147 & 45 \\
\hline Pertumbuhan Laba & Pearson Correlation & $.343^{*}$ & .337 & 1 \\
\cline { 2 - 5 } & Sig. (2-tailed) & .021 & 45 & 45 \\
\cline { 2 - 5 } & $\mathrm{N}$ & 45 & & \\
\hline *. Correlation is significant at the 0.05 level (2-tailed). & & \\
\hline
\end{tabular}

Berdasarkan hasil analisis korelasi pearson product moment, didapatkan angka pearson correlation sebesar 0.343 untuk return on asset terhadap pertumbuhan laba dan sebesar 0.147 untuk return on equity terhadap pertumbuhan laba. Berdasarkan hasil uji tersebut dapat dijelaskan merujuk pada tabel kategori koefisien korelasi, bahwa return on asset terhadap pertumbuhan laba berada pada interval korelasi $(0,20-0,399)$ yang mana dapat ditarik kesimpulan memiliki tingkat hubungan yang rendah dan return on equity terhadap pertumbuhan laba berada pada interval korelasi $(0,00-0,199)$ yang mana dapat ditarik kesimpulan memiliki tingkat hubungan yang sangat rendah.

\section{Uji Korelasi Berganda}

Korelasi ganda merupakan angka yang menunjukkan arah dan kuatnya hubungan antara dua variabel independen secara bersama-sama atau lebih dengan satu variabel dependen. Maka terdapat hasil seperti berikut:

Hasil Analisis Uji Korelasi Berganda

\begin{tabular}{|l|l|l|l|l|}
\hline \multicolumn{3}{|l|}{ Model Summary } \\
\hline Model & R & R Square & $\begin{array}{l}\text { Adjusted } \\
\text { Square }\end{array}$ & $\begin{array}{l}\text { R } \\
\text { Std. Error of the } \\
\text { Estimate }\end{array}$ \\
\hline 1 & $.352^{\mathrm{a}}$ & .124 & .082 & .467518 \\
\hline \multicolumn{5}{|l|}{ a. Predictors: (Constant), ROE, ROA } \\
\hline \multicolumn{4}{|l|}{ b. Dependent Variable: Pertumbuhan Lab } \\
\hline
\end{tabular}

Berdasarkan hasil analisis korelasi berganda yang dilihat pada tabel 4.8 diatas, maka didapatkan angka $\mathrm{R}$ sebesar 0,352. Berdasarkan hasil uji tersebut dapat dijelaskan merujuk pada tabel kategori koefisien korelasi masuk pada interval korelasi $(0,20$ $0,399)$ maka disimpulkan tingkat hubungan korelasi berganda dari return on asset dan return on equity terhadap pertumbuhan laba mempunyai tingkat hubungan yang rendah.

\section{Uji Hipotesis Statistik t}

Dalam penelitian uji $\mathrm{T}$ digunakan untu mengetahui ada atau tidaknya pengaruh yang signifikan Return on asset (X1), return on equity (X2) secara parsial terhadap pertumbuhan laba (Y). Dalam penelitian ini menggunakan uji dua pihak (two tails test)

Dari pengujian secara parsial dapat dilihat dari tabel berikut:

\section{Hasil Analisis Uji Hipotesis Statistik t}

\begin{tabular}{|l|}
\hline Coefficientsa \\
\hline
\end{tabular}




\begin{tabular}{|c|c|c|c|c|c|c|}
\hline \multirow{2}{*}{\multicolumn{2}{|c|}{ Model }} & \multicolumn{2}{|c|}{ Unstandardized Coefficients } & \multirow{2}{*}{$\begin{array}{c}\text { Standardized } \\
\text { Coefficients } \\
\text { Beta }\end{array}$} & \multirow[b]{2}{*}{$\mathrm{T}$} & \multirow[b]{2}{*}{ Sig. } \\
\hline & & B & Std. Error & & & \\
\hline \multirow[t]{3}{*}{1} & (Constant) & -.351 & .137 & & -2.557 & .014 \\
\hline & ROA & 5.766 & 2.607 & .327 & -2.212 & .032 \\
\hline & ROE & .265 & .505 & .078 & .525 & .603 \\
\hline & & abuhs & & & & \\
\hline
\end{tabular}

Dalam tabel diatas antara variabel return on asset terhadap pertumbuhan laba menunjukkan bahwa nilai thitung sebesar 2.212. Dengan melihat pada $t$ tabel jumlah data $\mathrm{n}=45$ dan $(\mathrm{df})=\mathrm{n}-\mathrm{k}$ atau $45-3=42$ pada tingkat kesalahan $\alpha=0,05$ dengan pengujian dua pihak maka diperoleh ttabel sebesar 1,682. Hal ini menujukkan bahwa thitung $\geq$ ttabel maka Ha diterima dan Ho ditolak. Artinya secara parsial terdapat pengaruh signifikan antara return on asset terhadap pertumbuhan laba

Sedangkan untuk variabel return on equity menunjukkan bahwa nilai thitung sebesar 0.525 . Dengan melihat pada ttabel jumlah data $n=45$ dan $(\mathrm{df})=n-k$ atau $45-3=42$ pada tingkat kesalahan $\alpha=0,05$ dengan pengujian dua pihak maka diperoleh ttabel sebesar 1,682. Ini menunjukkan bahwa hal ini menujukkan bahwa thitung $\leq$ ttabel maka Ho diterima dan Ha ditolak. Artinya secara parsial tidak terdapat pengaruh signifikan antara return on equity terhadap pertumbuhan laba.

\section{Uji Hipotesis Statistik f (Simultan)}

Uji $\mathrm{F}$ ini digunakan untuk mengetahui apakah variabel independen return on asset (X1) dan return on equity (X2) secara bersama-sama berpengaruh secara signifikan terhadap variabel dependen pertumbuhan laba (Y). Hasil uji $\mathrm{F}$ untuk menguji apakah model regresi yang dibuat signifikan atau non signifikan. Uji F dilakukan dengan cara membandingkan Fhitung dengan Ftabel, pedoman pengambilan keputusan hasil uji f adalah sebagai berikut:

A. Ha diterima, Ho ditolak: apabila probabilitas (signifikan) $<0,05(\alpha)$ atau Fhitung $>$ Ftabel.

B. Ha ditolak, Ho diterima: apabila probabilitas (signifikan ) $>0,05(\alpha)$ atau Fhitung $<$ Ftabel

Hasil Analisis Uji Hipotesis Statistik F (Simultan)

\begin{tabular}{|c|c|c|c|c|c|c|}
\hline \multicolumn{7}{|c|}{ ANOVAa } \\
\hline \multicolumn{2}{|c|}{ Model } & Sum of Squares & Df & Mean Square & $\mathrm{F}$ & Sig. \\
\hline \multirow[t]{3}{*}{1} & Regression & 1.294 & 2 & .647 & 2.961 & $.063^{\mathrm{b}}$ \\
\hline & Residual & 9.180 & 42 & .219 & & \\
\hline & Total & 10.474 & 44 & & & \\
\hline \multicolumn{7}{|c|}{ a. Dependent Variable: Pertumbuhan Laba } \\
\hline
\end{tabular}

Dari hasil derajat kebebasan (df) dapat dilihat dalam Ftabel sebesar 3,20, sehingga dapat ditentukan bahwa nilai Fhitung lebih kecil dari nilai Ftabel $(2.961<3,20)$ dengan nilai signifikansi adalah sebesar 0,005 dibawah dari $5 \%(\alpha=0,05)$. Dari hasil tersebut 
dapat di katakan bahwa return on asset dan return on equity secara bersama-sama (simultan) Tidak berpengaruh signifikan terhadap pertumbuhan laba.

\section{Pembahasan Hasil Penelitian}

Pada bagian ini menejelaskan tentang hasil penelitian yang dilakukan oleh peneliti dengan menggunakan data perusahaan sub sector Wholesale yang terdaftar di Bursa Efek Indonesia dengan data laporan keuangan pertahun sebanyak 45 data laporan keuangan.

\section{Pengaruh Return on asset Terhadap pertumbuhan laba}

Penelitian ini menggunakan sumber data yang didapat dari Bursa Efek Indonesia berdasarkan laporan keuangan yaitu per Tahun 2017 sampai dengan 2019. Data yang digunakan adalah laba bersih dan total asset. Berikut ini adalah pembahasan hasil penelitian return on asset terhadap pertumbuhan laba:

1. Hasil uji normalitas data ditunjukkan bahwa besarnya Asymptotic Significanted (2tailed) sebesar 0,095. Dimana kondisi ini menunjukan bahwa probabilitas $>0,05$ yang menyatakan bahwa data berdistribusi normal.

2. Hasil analisis koefisien korelasi product moment, besarnya koefisien korelasi antara variable return on asset dengan pertumbuhan laba berdasarkan hasil perhitungan yaitu sebesar 0.343 berada pada kategori interval $(0,20-0,399)$. Hal ini menunjukan antar variable memiliki tingkat hubungan yang rendah.

3. Berdasarkan hasil analisis uji hipotesis T-test secara parsial return on asset thitung sebesar 2.212 dan diperoleh ttabel sebesar 1,682 Hal ini menujukkan bahwa thitung $\geq$ ttabel maka $H o$ ditolak dan Ha diterima. Artinya, secara parsial terdapat pengaruh signifikan antara return on asset terhadap pertumbuhan laba.

\section{Pengaruh Return on Equity Terhadap Pertumbuhan Laba}

Penelitian ini menggunakan sumber data yang didapat dari Bursa Efek Indonesia berdasarkan laporan keuangan Tahun 2017 sampai dengan 2019. Data yang digunakan adalah laba bersih dan equity. Berikut ini adalah pembahasan hasil penelitian return on equity terhadap pertumbuhan laba:

1. Hasil uji normalitas data ditunjukkan bahwa besarnya Asymptotic Significanted (2tailed) sebesar 0,095. Dimana kondisi ini menunjukan bahwa probabilitas $>0,05$ yang menyatakan bahwa data berdistribusi normal.

2. Hasil analisis koefisien korelasi product moment, besarnya koefisien korelasi antara return on equity dengan pertumbuhan laba berdasarkan hasil perhitungan yaitu sebesar 0.147 berada pada kategori interval $(0,00-0,199)$. Hal ini menunjukan antar variable return on equity dan pertumbuhan laba memiliki tingkat hubungan yang sangat rendah.

3. Berdasarkan hasil analisis uji hipotesis T-test secara parsial return on equity memiliki $\mathrm{T}$ hitung sebesar 0.525 dan $\mathrm{T}$ Tabel 1,682 yang artinya $\mathrm{T}$ hitung $<\mathrm{T}$ tabel. Maka dapat disimpulkan bahwa hipotesis Ho diterima dan Ha ditolak. Artinya, secara parsial tidak terdapat pengaruh signifikan antara return on equity terhadap pertumbuhan laba.

Berdasarkan teori menurut Priyatno (2013: 114) Hal tersebut menunjukan ROE berpengaruh positif dan tidak signifikan terhadap pertumbuhan laba. Hal ini disebabkan oleh sifat dan pola investasi yang dilakukan oleh pihak perusahaan tidak tepat sehingga seluruh aktiva tidak digunakan secara efisien maka laba yang diperoleh tidak maksimal.

\section{Pengaruh Return on Asset dan Return on Equity Terhadap Pertumbuhan Laba}


Dalam penelitian ini peneliti bertujuan untuk menilai pengaruh return on asset sebagai variabel $\mathrm{X}_{1}$ dan return on equity $\mathrm{X}_{2}$ terhadap variabel dependen pertumbuhan laba Y dengan objek penelitian perusahaan sub sektor wholesale yang terdaftar di Bursa Efek Indonesia tahun 2017-2019.

Berikut ini adalah pembahasan hasil penelitian return on asset dan return on equity terhadap pertumbuhan laba:

1. Hasil analisis korelasi berganda didapatkan nilai $\mathrm{R}$ sebesar 0,352 berada pada kategori interval $(0,20-0,399)$ yang menunjukan return on asset dan return on equity secara simultan memiliki hubungan yang rendah terhadap pertumbuhan laba.

2. Hasil Uji regresi berganda didapatkan persamaan linear $\mathrm{Y}=-0.351+5.766 \mathrm{X} 1+0.265$ $\mathrm{X} 2$ yang menunjukan apabila return on asset dinaikan 1 maka pertumbuhan laba akan mengalami kenaikan sebesar 5,766 apabila return on equity dinaikan 1 maka pertumbuhan laba akan mengalami peningkatan sebesar 0,265

3. Berdasarkan hasil analisis uji hipotesis F-test secara simultan return on asset dan return on equity memiliki $F$ hitung sebesar 2.961 dan F Tabel 3,20 yang artinya F Hitung $<F$ Tabel. Maka dapat disimpulkan bahwa hipotesis $\mathrm{Ho}_{3}$ diterima dan $\mathrm{Ha}_{3}$ ditolak. Sehingga secara statistic dapat dinyatakan bahwa, return on asset dan return on equity secara simultan tidak berpengaruh signifikan terhadap pertumbuhan laba.

4. Hasil Analisis Koefisien Determinasi menunjukan bahwa return on asset dan return on equity terhadap pertumbuhan laba berpengaruh hanya sebesar $12,4 \%$ dan $87,6 \%$ lainnya dipengaruhi oleh faktor lain diluar penelitian ini.

Menurut (Harahap, 2015) Rasio pertumbuhan laba dipengaruhi oleh rasiorasio keuangan, antara lain current ratio, debt to asset ratio, total asset turnover dan net profit margin. Hal ini membuktikan bahwa faktor lain diluar return on asset dan dan return on equity selama periode 2017-2019 terutama di sektor konstruksi sangat mempengaruhi pertumbuhan laba yang menjadi bahan pertimbangan bagi investor.

\section{KESIMPULAN DAN SARAN}

Pada bagian ini berisi tentang hasil dari pengujian yang telah di lakukan dan masukan untuk pengguna penelitian selanjutnya

\section{Kesimpulan}

Berdasarkan identifikasi masalah, hipotesis dan hasil pengujian yang telah dilakukan untuk mengetahui pengaruh return on asset dan return on equity terhadap pertumbuhan laba maka dapat disimpulkan sebagai berikut:

4. Hasil uji hipotesis antara return on asset dan pertumbuhan laba menunjukan bahwa terdapat pengaruh yang signifikan antara return on asset terhadap pertumbuhan laba pada perusahaan subsektor wholesale yang terdaftar di Bursa Efek Indonesia tahun 2017-2019

5. Hasil uji hipotesis antara return on equity dan pertumbuhan laba menunjukan bahwa tidak terdapat pengaruh yang signifikan antara return on equity terhadap pertumbuhan laba pada perusahaan subsektor wholesale yang terdaftar di Bursa Efek Indonesia tahun 2017-2019

6. Hasil uji hipotesis antara return on asset dan return on equity terhadap pertumbuhan laba menunjukan bahwa tidak terdapat pengaruh yang signifikan antara return on asset dan return on equity terhadap pertumbuhan laba pada perusahaan subsektor wholesale yang terdaftar di Bursa Efek Indonesia tahun 2017-2019 


\section{Saran}

Berdasarkan dari hasil kesimpulan maka saran yang diberikan untuk penelitian selanjutnya adalah sebagai berikut:

1. Sampel untuk penelitian selanjutnya diharapkan tidak hanya perusahaan pada perusahaan sub sektor wholesale saja. Tetapi juga perusahaan di sektor lain. Seperti sektor industri barang konsumsi dan sektor telekomunikasi

2. Jangka waktu penelitian dapat diperpanjang dengan memperluas tahun pengamatan agar hasil penelitian lebih dapat menjelaskan hubungan pengaruh dan keakuratan dari return on asset dan return on equity perlu dikembangkan atau diperbanyak lagi.

3. Penambahan variable independen untuk mengetahui faktor lain. Karena banyak faktor lain yang diduga yang dapat mempengaruhi pertumbuhan laba selain return on asset dan return on equity. Seperti gross profit margin, net profit margin

\section{DAFTAR PUSTAKA}

Bionda, A. R., \& Mahdar, N. M. (2017). Pengaruh Gross Profit Margin, Net Profit Margin, Return on Asset, dan Return on Equity terhadap Pertumbuhan Laba pada Perusahaan Manufaktur di Bursa Efek Indonesia. Jurnal Bisnis dan Ekonomi, 4.

Harahap, S. S. (2015). Analisis Kritis atas Laporan Keuangan. Jakarta: Rajawali Pers.

Hery. (2015). Analisis Laporan Keuangan. Yogyakarta: Center of Academic Publihsing Center.

Ikhwal, N. (2016). Analisis ROA dan ROE Terhadap Profitabilatas Bank di Bursa Efek Indonesia. Jurnal Lembaga Keuangan dan Perbankan Volume 1, 3.

Kasmir. (2015). Analisis Laporan Keuangan. Jakarta: Rajawali Pers.

Munawir. (2015). Analisis Laporan Keuangan. Jakarta: Salemba Empat.

PSAK. (2015). Tentang Laporan Keuangan - Edisi Revisi. Jakarta: Dewan Standar Akuntansi keuangan.

Safitri, A. M., \& Mukaram. (2018). Pengaruh ROA, ROE, dan NPM Terhadap Pertumbuhan Laba Pada Perusahaan Sektor Industri Barang Konsumsi Yang Terdaftar di Bursa Efek Indonesia. Riset Bisnis dan Inverstasi, 4. 